\title{
OPTIMAL CONFIGURATION FOR WORKSHOP MANUFACTURING SYSTEM UNDER DUAL RESOURCE CONSTRAINTS
}

\author{
Wang, Y.,\#; Cen, H. J.* \& Yang, O.** \\ *School of Electronical and Communication Engineering, Shenzhen Polytechnic, Shenzhen 518055, \\ China \\ ** School of Computer Engineering, Shenzhen Polytechnic, Shenzhen 518055, China \\ E-Mail: wyang@szpt.edu.cn ( ${ }^{\#}$ Corresponding author)
}

\begin{abstract}
In view of the defects of simulation modelling and resource optimization algorithm for small-batch multi-variety job-shops, this paper presents a mathematical model and simulation model which considers the dual resources optimization of both manpower and equipment to minimize the investment in the overall job-shop under the condition of satisfying the requirement of average productivity and average production cycle. The mathematical model established simplifies the solving process of traditional optimization algorithm and replaces the optimal solution of the original problem with the obtained approximate solution. The job-shop dual resource optimization simulation system model is constructed to verify the mathematical model proposed. The simulation results verify the effectiveness of the results of the mathematical model. This paper also designs the multi-agent system and the dual resources optimization-based job-shop entity flow. The simulation results show that when the job-shop workers and processing equipment are within a certain range, the appropriate increase of the buffer zone in the equipment room can effectively enlarge the system's capacity. With the further rise of the buffer zone number, the system's capacity will no longer increase. Under the ideal scheduling strategy, the utilization ratio of equipment and labour efficiency can reach the maximum value.

(Received, processed and accepted by the Chinese Representative Office.)
\end{abstract}

Key Words: Job-Shop, Production Cycle, Capacity Restriction, Dual Resource, Optimization, Simulation

\section{INTRODUCTION}

The unit style streamlined job-shop is the main operation mode of small-batch multi-variety production enterprises [1-3]. Such job-shops are composed of multiple units with similar functions. Product components of different varieties are processed through independent units. The product processing and transportation directions are the same in the job-shop. Such jobshop features large flexibility, simple management and high efficiency [4-8].

The DRC (dual resources constraint)-based unit style flow shop is developed on the basis of traditional job-shop. It takes the factors of production equipment and labour into consideration in production scheduling [9-12]. Because of the high degree of automation of the equipment in such job-shops, the processing time of a single product on the equipment is long, which will cause product blockage easily. Therefore, the capacity and the production cycle do not match. At the same time, the higher the degree of automation is, the fewer operators are needed. There will be a mismatch between the number of devices and the number of manpower and the equipment and labour costs are high [13-18]. Therefore, the optimization scheduling of resources of the job-shop that considers the production cycle and capacity constraints is the prerequisite condition to reducing production cost and further improve the production efficiency of the job-shop and is of important practical significance [19]. 
The small-batch multi-variety job-shop has its fixed characteristics. The optimization of this kind of job-shop mainly considers the scheduling mode and the overall layout of the jobshop. There is still great space for doing research on the planning and configuration of dual resource constraints [20-24]. The resources optimization algorithm in related literature includes genetic algorithm, neural network and local search algorithm. When the dimension of the problems to be solved is large and the constraint condition cannot be described in closed form, the calculation error of the abovementioned methods is relatively large [25-26].

Aiming at the defects of the simulation modelling and resource optimization algorithm of the small-batch multi-variety job-shop, this paper puts forward a kind of mathematical model and simulation model that considers the dual resources optimization of both manpower and equipment to minimize the investment in the overall job-shop under the condition of satisfying the requirement of average productivity and average production cycle. The feasibility of the results obtained by the mathematical model is verified by the established simulation model.

\section{PROBLEM DESCRIPTION}

The objective function of this paper is to minimize the total cost of the system under the premise of considering capacity constraints and system production cycle. The objective function of this paper is to minimize the total cost of the system under the premise of considering capacity constraints and system production cycle [27-32]. The job-shop mainly includes four kinds of production units, namely, cavity numerical control (CNC), electrode and component finish machining, electrical discharge machining (EDM). The typical product processing flow chart is shown in Fig. 1. In each unit, the staff members are arranged to engage in early preparatory works such as tool setting and proofreading and late work of disassembly and inspection.

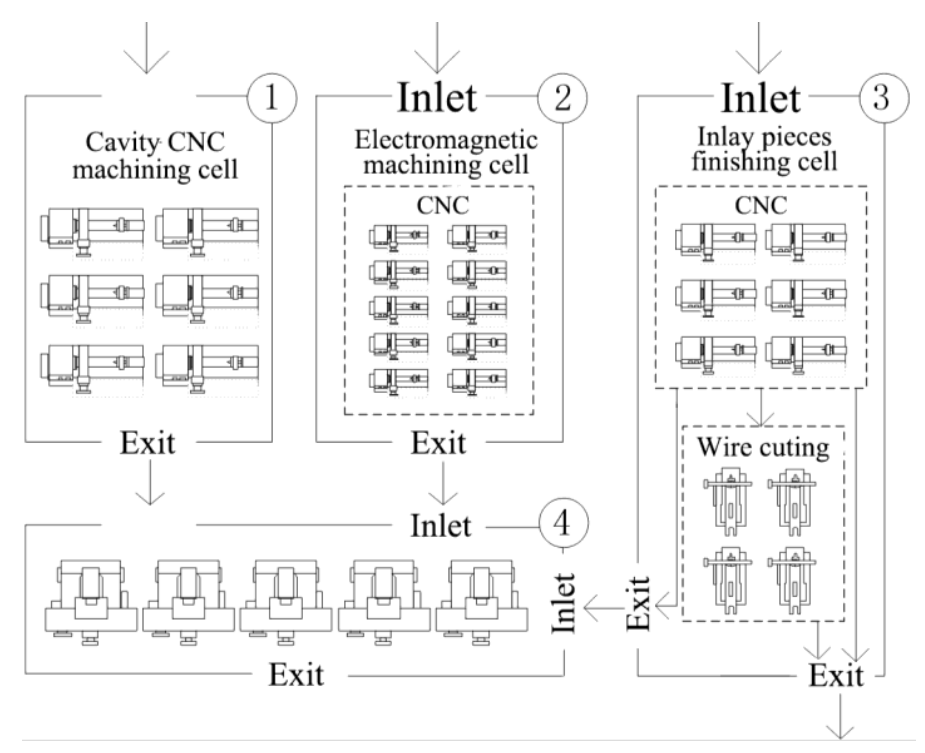

Figure 1: Flow chart of job-shop production.

To make the calculation result more accurate, the following assumptions are made: The product's demand type and demand quantity are fixed. The staff and equipment of each jobshop unit cannot be shared with other units. The product processing time is fixed. The purchase cost of the equipment and the daily working hours are known. The working hours and total cost of wages are known.

Fig. 2 demonstrates the method for transforming the optimization problem of the object function model to approximation analysis. $X$ and $Y$ in the figure are the resources allocation 
and Buffer configuration vector respectively. $R$ is the labour resources vector; $\eta$ is the scheduling policy vector; $\alpha$ is the pre-set average production capacity.

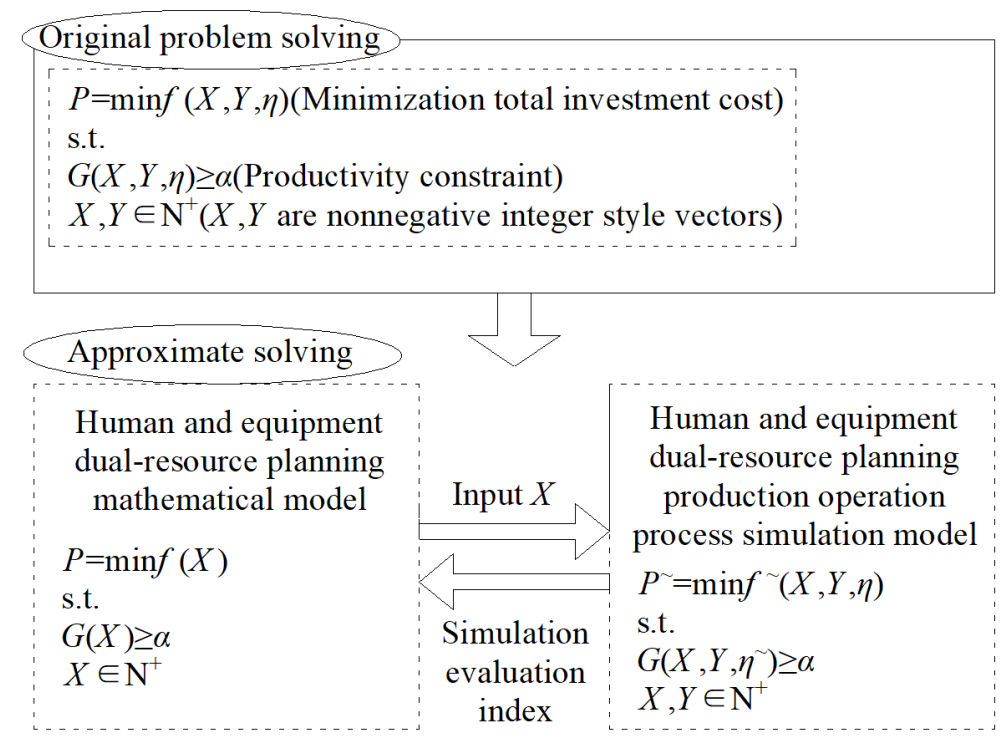

Figure 2: Approximation analysis method of the optimal problem of the model.

In order to make the total cost $\mathrm{P}$ of enterprise minimized, $X^{*}, Y^{*}$ and $\eta^{*}$ must reach the optimal value and $G\left(X^{*}, Y^{*}, \eta\right)>\alpha$. Since the traditional algorithm cannot be used to describe this problem, the constraint condition that the total supply quantity is larger than the total demand quantity is introduced and the above method is viewed approximately as a double resources model which only considers the staff and equipment. When the difference between the $P$ value obtained using the approximation model and the $P$ value obtained using the original objective function is smaller than $5 \%$, it is considered that the approximation solving algorithm can meet the calculation requirements.

The order type is the premise of establishing mathematical model and simulation model. After the order type is determined, the total amount of resources such as equipment and staff can be figured out. Meanwhile, the simulation process can be more detailed and can better meet the actual production requirements of the enterprise.

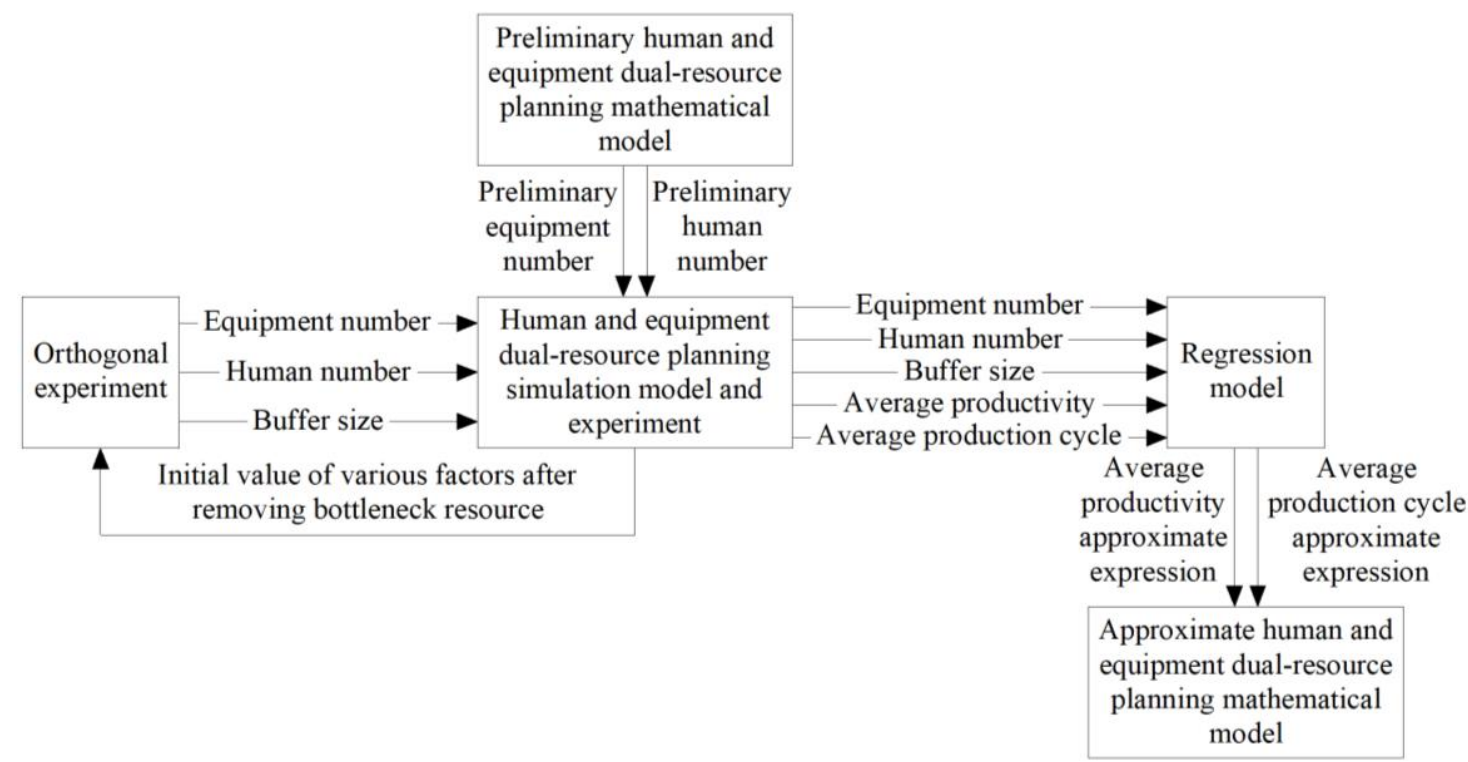

Figure 3: The solving process of the double resources-based job-shop optimization configuration problem. 
It is assumed that there are three kinds of products $\mathrm{A}, \mathrm{B}$ and $\mathrm{C}$ in a job-shop. All these products are produced after three working procedures: $\mathrm{CNC}$, electrodes and parts finish machining. The solving process of the double resources-based job-shop optimization configuration problem using the established mathematical model and simulation model is as shown in Fig. 3.

\section{MATHEMATICAL MODEL BASED ON DOUBLE RESOURCE OPTIMIZATION}

The following mathematical model for production optimization can be obtained based on the problem description in the second section:

$$
\begin{gathered}
P=\min f(X, R, Y, \eta) \\
\Theta(X, R, Y, \eta) \geq \alpha \\
T(X, R, Y, \eta) \leq b \\
S(X, R) \geq R(X, R) \\
X, R, Y \in \mathrm{N}^{+}
\end{gathered}
$$

Eq. (1) refers to the object function to be sought. Eqs. (2) and (3) stand for the average capacity restriction and average production period restriction respectively. $b$ is the average production period. Eq. (4) means that the actual production time shall not be less than the minimum production hours required in Eq. (1). Eq. (5) means that vectors $X, Y$ and $R$ are nonnegative values.

On the basis of Eqs. (1) to (5), the resources optimization mathematical model after the constraint loosens is figured out and is shown as follows:

$$
\begin{gathered}
\min _{x_{k} \in N} P=\sum_{k=1}^{m} c_{k} x_{k}+\sum_{j=1}^{p} \delta\left(s_{j}+r_{j}\right) \\
v_{k} u_{k}\left(x_{k}+g_{k}\right) \geq \sum_{i=1}^{n} \sum_{j=1}^{p} \sum_{l=1}^{e_{i}}\left(\alpha_{i j k l}+\beta_{i j k l}+\gamma_{i j k l}\right) \mu_{i j k l}, k=1,2, \ldots, m \\
\eta s_{j} h d \geq \sum_{i=1}^{n} \sum_{j=1}^{p} \sum_{l=1}^{e_{i}} \beta_{i j k l} \mu_{i j k l}, j=1,2, \ldots, p \\
\eta s_{j} h d \geq \sum_{i=1}^{n} \sum_{j=1}^{p} \sum_{l=1}^{e_{i}} \gamma_{i j k l} \mu_{i j k l}, j=1,2, \ldots, p \\
x_{k} \in \mathrm{N}, s_{j} \in \mathrm{N}, r_{j} \in \mathrm{N}, i=1,2, \ldots, n, \\
j=1,2, \ldots, p, k=1,2, \ldots, m, l=1,2, \ldots, e_{i}
\end{gathered}
$$

$i, j, k$ and $l$ refer to the serial number of the product component type, the serial number of unit, the serial number of equipment species and the serial number of equipment production, respectively; $e$ is the total amount of the equipment process; $h$ is the daily working hours of the employees; $d$ is the number of working days per year; $\beta_{i j k l}$ and $\gamma_{i j k l}$ refer to the early-stage preparation and later cleaning time for the $l^{\text {th }}$ working procedure for producing the $i^{\text {th }}$ product on the $k^{\text {th }}$ equipment; $\delta$ is the staff's salary; $g_{k}$ is the total number of existing equipment; $c_{k}$ is the equipment purchase price.

Eq. (7) means that the product demand and supply match the job-shop capacity. Eqs. (8) and (9) suggest that the employee's working time should meet the actual production needs. Eq. (10) suggests that the three parameters must be integers. 


\section{SIMULATION MODEL BASED ON DUAL RESOURCE OPTIMIZATION}

The overall design framework of the simulation model system is shown in Fig. 4. The main parts of the system include the overall scheduling of the job-shop, operation scheduling of each processing unit, human-computer interaction, simulation data and other modules.

The multi-agent system (MAS) is based on artificial intelligence. The simulation system modelling based on dual resources optimization is carried out using MAS. The comprehensive regulation is made in each sub-unit job-shop through taking advantage of such features of MAS as high intellectuality, autonomy and scalability. The MAS established is shown in Fig. 5, which contains order generation Agent, coordination dispatching Agent and execution Agent.

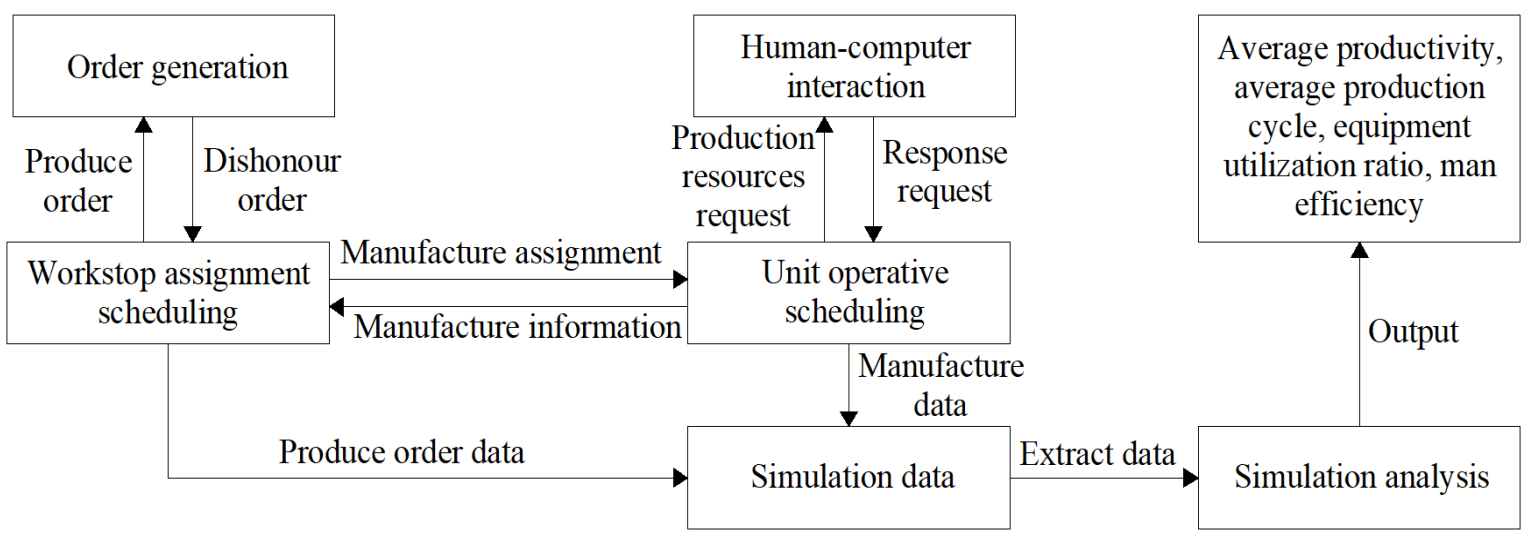

Figure 4: Overall framework of the simulation model design.

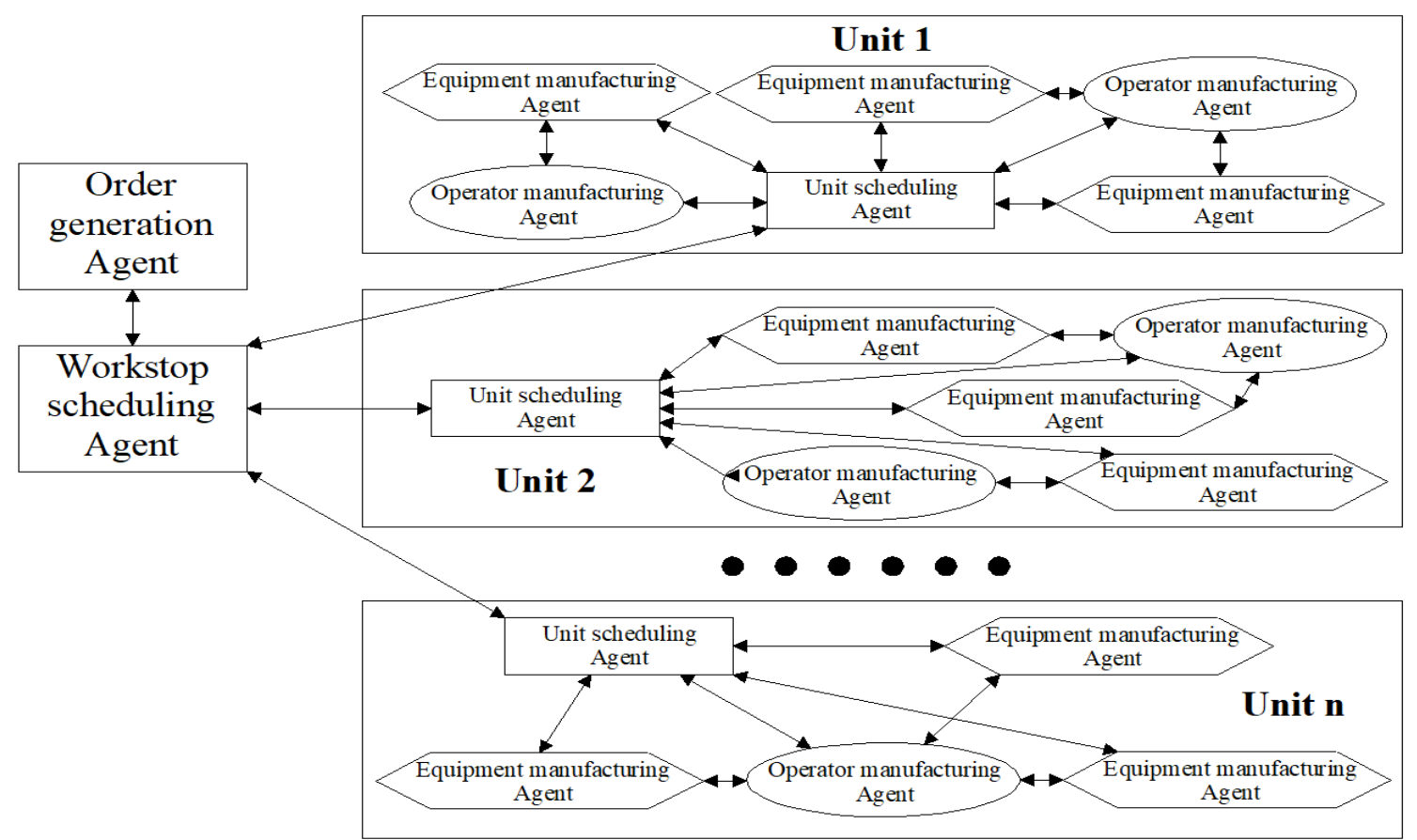

Figure 5: Agent structure of the simulation model established.

The double resource optimization-based job-shop physical flowchart is established according to Figs. 4 and 5. The flow chart takes the product component as the main line, and the product will pass through the buffer zone, processing zone and assembly area successively. Firstly, the working status of the equipment and operators is analysed. When the 
processing zone can process products, the product order enters the state of accepting arrangement and waiting for processing. When the products enter the processing zone, if other products are being processed, the product will enter the buffer zone to wait. The overall jobshop is divided into several processing queues. Each subunit job-shop shall pre-set the processing queue of the product parts for comprehensive management.

The job-shop physical flow shown in Fig. 6 is simulated using eM-plant software and the double resources optimization simulation model which considers both equipment and labour is obtained. The model includes six parts, such as cavity, electrode and wire-electrode cutting. The number of employees and equipment is figured out using the mathematical model in section 3 and the products are processed on the first come first served basis.

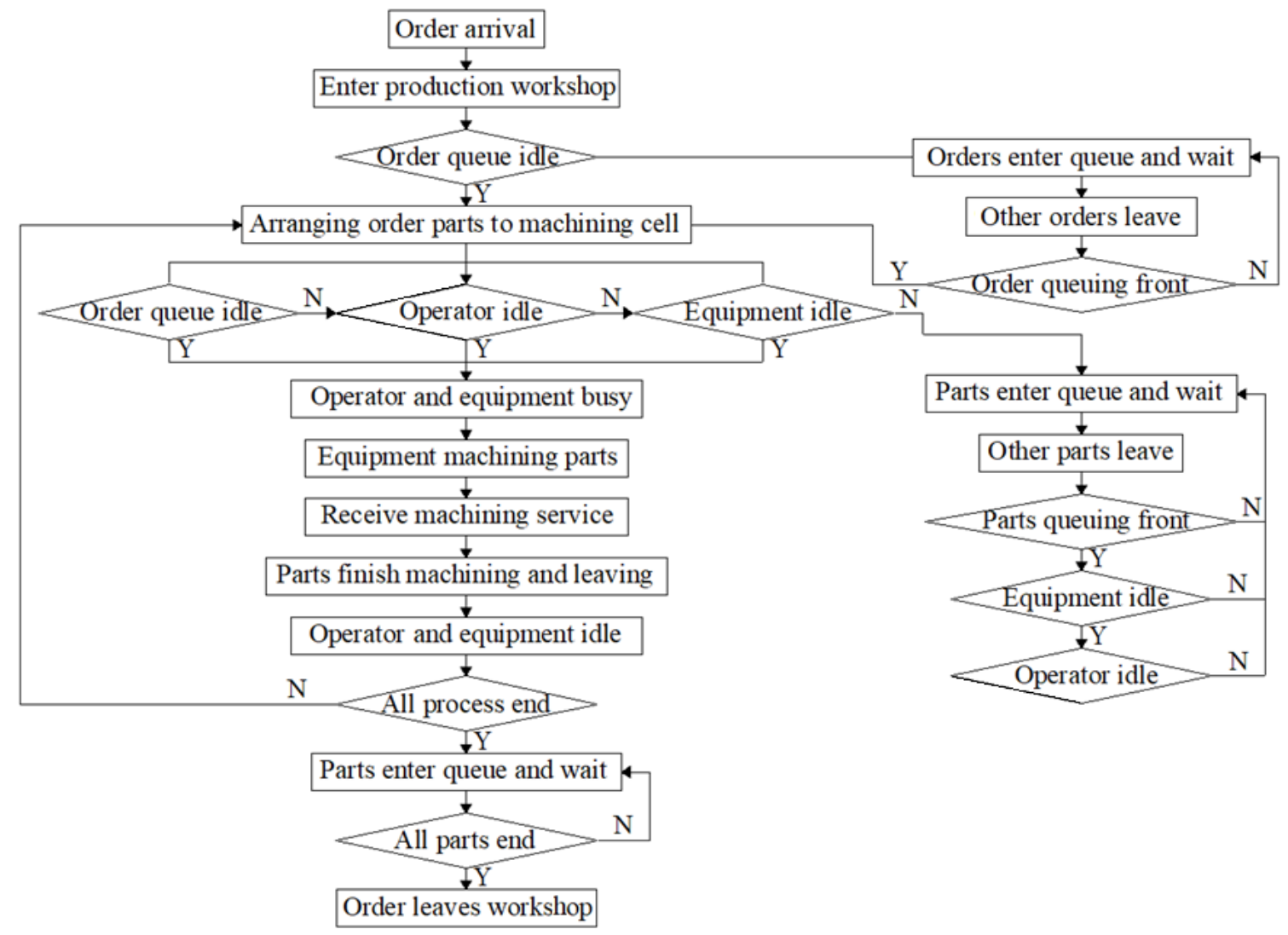

Figure 6: Physical flow chart of the job-shop based on double resources optimization.

\section{EXAMPLE VERIFICATION}

The product order type and related parameters are obtained from Table I. The buffer zone in the job-shop is pre-set according to the maximum value of the three orders. In the early stage, the simulation model was used to calculate the number of equipment coming to a steady state, the number of workers and equipment utilization rate after 500 days of processing in the jobshop. The relationship between the quantity of buffer and the capacity is shown in Fig. 7. The ratio of equipment utilization and worker efficiency in different processes is shown in Fig. 8.

It can be seen from Fig. 7 that at the early stage, with the constant rising of the number of buffer, the production capacity of the job-shop system also gradually increases. When the number of buffer reaches 10 , the capacity reaches the maximum value, which is 236 . That is to say, when the workers and processing equipment are in a certain scope, the appropriate addition of buffers in the equipment room can effectively expand the system's productivity. With the further expansion of the buffer quantity, the system's production capacity will no longer expand. 
Wang, Cen, Yang: Optimal Configuration for Workshop Manufacturing System under Dual ...

Table I: Related parameters of the product order model.

\begin{tabular}{|c|c|c|c|c|c|c|c|}
\hline $\begin{array}{l}\text { Order } \\
\text { style }\end{array}$ & $\begin{array}{l}\text { Workpiece } \\
\text { style }\end{array}$ & $\begin{array}{c}\text { Cell } \\
\text { serial } \\
\text { number } \\
j\end{array}$ & $\begin{array}{c}\text { Process } \\
\text { name }\end{array}$ & $\begin{array}{l}\text { Equipment set } \\
\text { numbering } k\end{array}$ & $\begin{array}{l}\text { Production } \\
\text { time per } \\
\text { piece } \alpha_{i j k l} \\
\text { (h) }\end{array}$ & $\begin{array}{l}\text { Clamping } \\
\text { standard } \\
\text { operation } \\
\text { time } \beta_{i j k l}(\mathrm{~h})\end{array}$ & $\begin{array}{l}\text { Dismantling } \\
\text { standard } \\
\text { operation } \\
\text { time } \gamma_{i j k l}(\mathrm{~h})\end{array}$ \\
\hline \multirow{4}{*}{ A } & \multirow{4}{*}{$\begin{array}{c}\text { Cavity } \\
\text { Electrode } \\
\text { Inlay pieces }\end{array}$} & 1 & $\mathrm{CNC}$ & Five-axis CNC & 49 & 3.0 & 0.9 \\
\hline & & 4 & EDM & Electric spark & 50.3 & 2.0 & 0.5 \\
\hline & & 2 & $\mathrm{CNC}$ & Five-axis CNC & 2 & 1.0 & 0.5 \\
\hline & & 3 & EDM & Five-axis CNC & 19 & 2.0 & 0.4 \\
\hline \multirow{5}{*}{ B } & \multirow{5}{*}{$\begin{array}{c}\text { Cavity } \\
\text { Electrode } \\
\text { Inlay pieces }\end{array}$} & 1 & $\mathrm{CNC}$ & Five-axis CNC & 39 & 3.0 & 0.9 \\
\hline & & 4 & EDM & Electric spark & 14 & 2.0 & 0.5 \\
\hline & & 2 & $\mathrm{CNC}$ & Five-axis CNC & 0.9 & 1.0 & 0.5 \\
\hline & & 3 & $\mathrm{CNC}$ & Five-axis CNC & 24 & 2.0 & 0.4 \\
\hline & & 3 & $\begin{array}{l}\text { Wire } \\
\text { cutting }\end{array}$ & $\begin{array}{c}\text { Wire cutting } \\
\text { machine }\end{array}$ & 5 & 0.9 & 0.4 \\
\hline \multirow{6}{*}{$\mathrm{C}$} & \multirow{3}{*}{ Cavity } & 1 & $\mathrm{CNC}$ & Five-axis CNC & 66 & 3.0 & 0.9 \\
\hline & & 4 & EDM & Electric spark & 24.2 & 2.0 & 0.5 \\
\hline & & 2 & $\mathrm{CNC}$ & Five-axis CNC & 2.2 & 1.0 & 0.5 \\
\hline & \multirow{2}{*}{ Electrode } & 3 & $\mathrm{CNC}$ & Five-axis CNC & 27 & 2.0 & 0.4 \\
\hline & & 3 & $\begin{array}{l}\text { Wire } \\
\text { cutting }\end{array}$ & $\begin{array}{l}\text { Wire cutting } \\
\text { machine }\end{array}$ & 2.8 & 0.9 & 0.4 \\
\hline & Inlay pieces & $\begin{array}{l}4 \\
4\end{array}$ & EDM & Electric spark & 3.6 & 0.9 & 0.4 \\
\hline
\end{tabular}

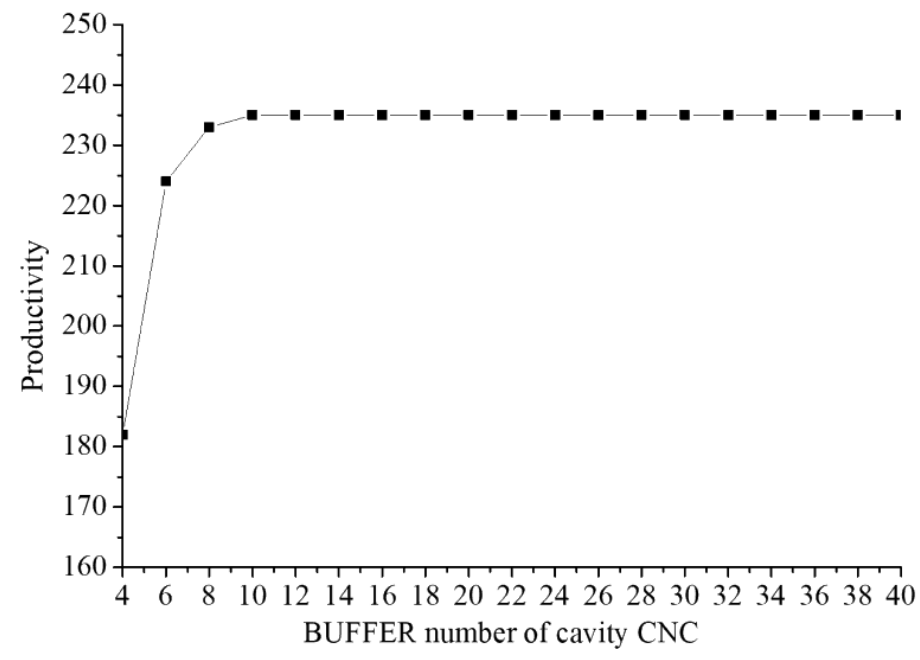

Figure 7: Relation curve of the quantity of buffer and production capacity.

As shown in Fig. 8, when the utilization ratio of the insert unit is $100 \%$, the utilization ratio of the cavity, electric spark and electrode is $81 \%, 94 \%$ and $88 \%$ respectively, while the working efficiency of the labour force is $76 \%$. It can be learned from the calculation of the mathematical model that under the ideal scheduling strategy, the equipment utilization rate and labour working efficiency can reach the maximum value. However, in reality, when the target production capacity is achieved, additional costs need to be invested. It can also be learned from the figure that the insert unit is the bottleneck resource in the job-shop.

The bottleneck of the insert unit can be eliminated through six groups of simulation experiment, and the scheme of double resource optimization can be obtained. The test results are shown in Fig. 9. Test 3 can meet the pre-set target production capacity, while other experiments show different levels of bottleneck problems. The experiment 3 better controls the equipment expenditure cost, and the overall equipment compliance is fairly reasonable. 


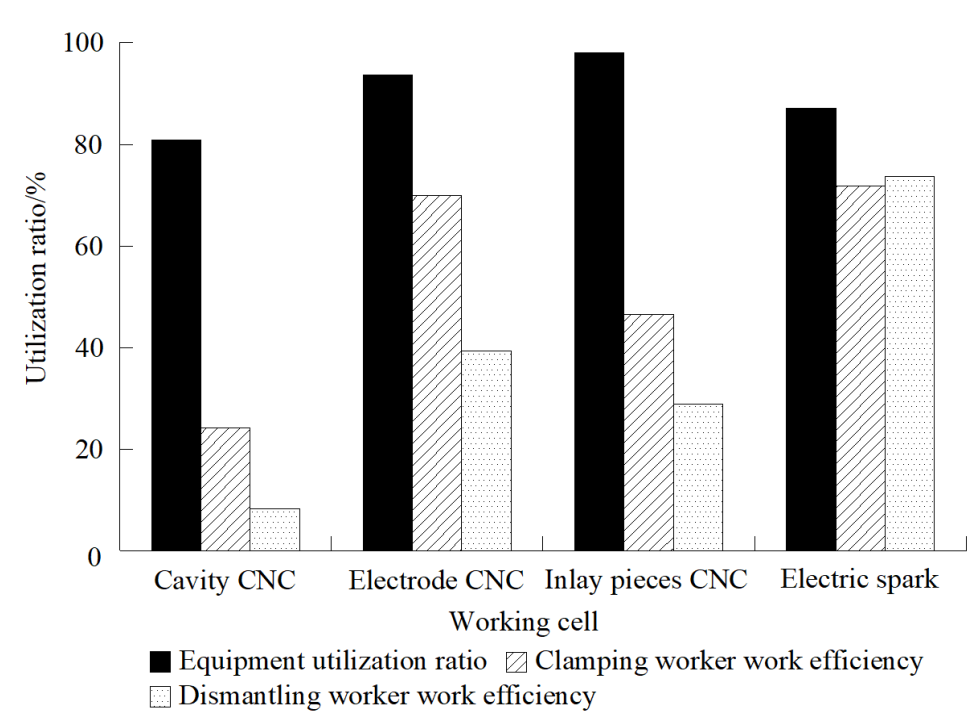

Figure 8: Comparison bar chart of equipment utilization and worker efficiency under different working procedures.

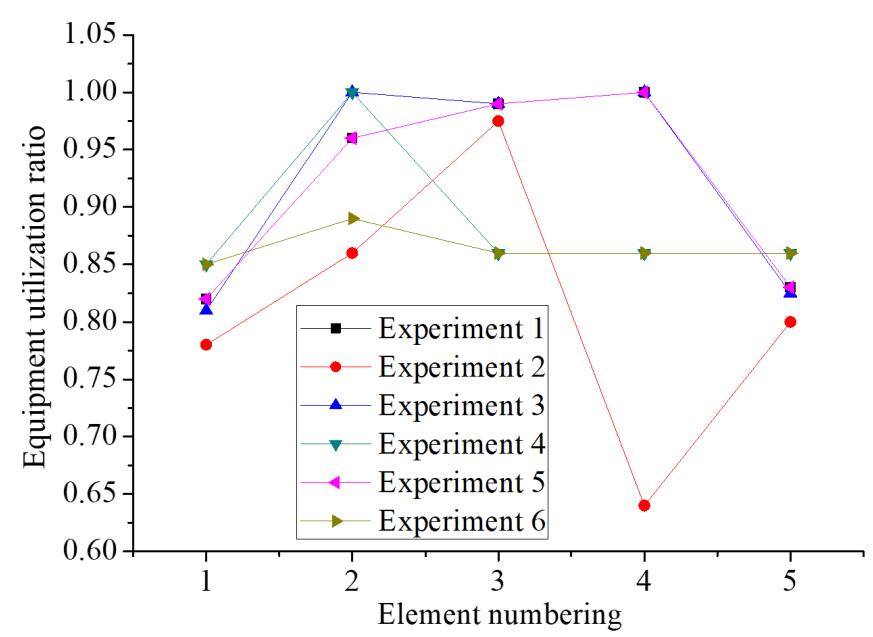

Figure 9: Utilization rate of each unit device under 6 experiments.

\section{CONCLUSION}

In view of the defects of simulation modelling and resource optimization algorithm for smallbatch multi-variety job-shops, this paper presents a mathematical model and simulation model which considers the dual resources optimization of both manpower and equipment to minimize the investment in the overall job-shop under the condition of satisfying the requirement of average productivity and average production cycle.

The proposed model is verified taking the data of an actual job-shop as example. The research conclusions are as follows:

(1) A kind of linear programming mathematical model with loose constraint is established, which simplifies the solving process of the traditional optimization algorithm. The approximate solution obtained replaces the optimal solution of the original problem. The mathematical model is verified by the double resource optimization-based simulation system model in the job-shop, and the simulation results validate the effectiveness of the results obtained using the mathematical model. The multi-agent system (MAS) and double resources optimization-based job-shop physical procedure are designed.

(2) The simulation experiment results show that when the workers and processing equipment are in a certain scope, the appropriate addition of buffers in the equipment room 
can effectively expand the system's productivity. With the further expansion of the buffer quantity, the system's production capacity will no longer expand. Under the ideal scheduling strategy, the utilization rate of the equipment and labour force working efficiency can reach the maximum value.

\section{REFERENCES}

[1] Xu, J.; Xu, X.; Xie, S. Q. (2011). Recent developments in dual resource constrained (DRC) system research, European Journal of Operational Research, Vol. 215, No. 2, 309-318, doi:10.1016/j.ejor.2011.03.004

[2] Bokhorst, J. A. C.; Slomp, J.; Gaalman, G. J. C. (2004). On the who-rule in dual resource constrained (DRC) manufacturing systems, International Journal of Production Research, Vol. 42, No. 23, 5049-5074, doi:10.1080/00207540410001733878

[3] Salum, L.; Araz, Ö. U. (2009). Using the when/where rules in dual resource constrained systems for a hybrid push-pull control, International Journal of Production Research, Vol. 47, No. 6, 1661-1677, doi:10.1080/00207540701579530

[4] Zupan, H.; Herakovic, N.; Zerovnik, J.; Berlec, T. (2017). Layout optimization of a production cell, International Journal of Simulation Modelling, Vol. 16, No. 4, 603-616, doi:10.2507/ijsimm16(4)4.396

[5] Zülch, G.; Bogus, T.; Koruca, H. I.; Kurbanoglu, C.; Brinkmeier, B. (2004). Simulation aided design of organizational structures in manufacturing systems using structuring strategies, Journal of Intelligent Manufacturing, Vol. 15, No. 4, 431-437, doi:10.1023/b:jims.0000034105.42204.f6

[6] Sammarco, M.; Fruggiero, F.; Neumann, W. P.; Lambiase, A. (2014). Agent-based modelling of movement rules in DRC systems for volume flexibility: human factors and technical performance, International Journal of Production Research, Vol. 52, No. 3, 633-650, doi: $10.1080 / 00207543.2013 .807952$

[7] Lei, D.; Guo, X. (2014). Variable neighbourhood search for dual-resource constrained flexible job shop scheduling, International Journal of Production Research, Vol. 52, No. 9, 2519-2529, doi: $10.1080 / 00207543.2013 .849822$

[8] Zheng, X.; Wang, L. (2016). A knowledge-guided fruit fly optimization algorithm for dual resource constrained flexible job-shop scheduling problem, International Journal of Production Research, Vol. 54, No. 18, 5554-5566, doi:10.1080/00207543.2016.1170226

[9] Can, B.; Heavey, C. (2011). Comparison of experimental designs for simulation-based symbolic regression of manufacturing systems, Computers \& Industrial Engineering, Vol. 61, No. 3, 447462, doi:10.1016/j.cie.2011.03.012

[10] Araz, Ö. U.; Salum, L. (2010). A multi-criteria adaptive control scheme based on neural networks and fuzzy inference for DRC manufacturing systems, International Journal of Production Research, Vol. 48, No. 1, 251-270, doi:10.1080/00207540802471256

[11] Hon, K. K. B.; Xu, S. (2007). Impact of product life cycle on manufacturing systems reconfiguration, CIRP Annals - Manufacturing Technology, Vol. 56, No. 1, 455-458, doi:10.1016/j.cirp.2007.05.109

[12] Gupta, A.; Jain, P. K.; Kumar, D. (2015). Configuration selection of reconfigurable manufacturing system based on performance, International Journal of Industrial \& Systems Engineering, Vol. 20, No. 2, 209-230, doi:10.1504/ijise.2015.069543

[13] Cesaní, V. I.; Steudel, H. J. (2005). A study of labor assignment flexibility in cellular manufacturing systems, Computers \& Industrial Engineering, Vol. 48, No. 3, 571-591, doi:10.1016/j.cie.2003.04.001

[14] Bokhorst, J. A. C.; Gaalman, G. J. C. (2009). Cross-training workers in dual resource constrained systems with heterogeneous processing times, International Journal of Production Research, Vol. 47, No. 22, 6333-6356, doi:10.1080/00207540802350724

[15] Zamiska, J. R.; Jaber, M. Y.; Kher, H. V. (2007). Worker deployment in dual resource constrained systems with a task-type factor, European Journal of Operational Research, Vol. 177, No. 3, 1507-1519, doi:10.1016/j.ejor.2005.04.018 
[16] Yue, H.; Slomp, J.; Molleman, E.; Van Der Zee, D. J. (2008). Worker flexibility in a parallel dual resource constrained job shop, International Journal of Production Research, Vol. 46, No. 2, 451-467, doi: $10.1080 / 00207540601138510$

[17] Malhotra, M. K.; Fry, T. D.; Kher, H. V.; Donohue, J. M. (1993). The impact of learning and labor attrition on worker flexibility in dual resource constrained job shops, Decision Sciences, Vol. 24, No. 3, 641-664, doi:10.1111/j.1540-5915.1993.tb01296.x

[18] Felan, J. T.; Fry, T. D. (2001). Multi-level heterogeneous worker flexibility in a dual resource constrained (DRC) job-shop, International Journal of Production Research, Vol. 39, No. 14, 3041-3059, doi:10.1080/00207540110047702

[19] Elvers, D. A.; Treleven, M. D. (1985). Job-shop vs. flow-shop routing in a dual resource constrained system, Decision Sciences, Vol. 16, No. 2, 213-222, doi:10.1111/j.15405915.1985.tb01484.x

[20] Kher, H. V. (2000). Examination of flexibility acquisition policies in dual resource constrained job shops with simultaneous worker learning and forgetting effects, Journal of the Operational Research Society, Vol. 51, No. 5, 592-601, doi:10.1057/palgrave.jors.2600935

[21] Hamedi, M.; Esmaeilian, G. R.; Ismail, N.; Ariffin, M. K. A. (2012). Capability-based virtual cellular manufacturing systems formation in dual-resource constrained settings using Tabu search, Computers \& Industrial Engineering, Vol. 62, No. 4, 953-971, doi:10.1016/j.cie.2011.12.020

[22] Kannan, V. R.; Jensen, J. B. (2004). Learning and labour assignment in a dual resource constrained cellular shop, International Journal of Production Research, Vol. 42, No. 7, 14551470, doi: $10.1080 / 00207540310001639964$

[23] Kher, H. V.; Fredendall, L. D. (2004). Comparing variance reduction to managing system variance in a job shop, Computers \& Industrial Engineering, Vol. 46, No. 1, 101-120, doi:10.1016/j.cie.2003.11.002

[24] ElMaraghy, H.; Patel, V.; Abdallah, I. B. (2000). Scheduling of manufacturing systems under dual-resource constraints using genetic algorithms, Journal of Manufacturing Systems, Vol. 19, No. 3, 186-201, doi:10.1016/S0278-6125(00)80011-4

[25] Bitran, G. R.; Morabito, R. (1999). An overview of tradeoff curves in manufacturing systems design, Production \& Operations Management, Vol. 8, No. 1, 56-75, doi:10.1111/j.19375956.1999.tb00061.x

[26] Karthikeyan, S.; Saravanan, M.; Rajkumar, M. (2016). Optimization of worker assignment in dynamic cellular manufacturing system using genetic algorithm, Journal of Advanced Manufacturing Systems, Vol. 15, No. 1, 35-42, doi:10.1142/s0219686716500049

[27] Kher, H. V.; Malhotra, M. K. (1994). Acquiring and operationalizing worker flexibility in dual resource constrained job shops with worker transfer delays and learning losses, Omega, Vol. 22, No. 5, 521-533, doi:10.1016/0305-0483(94)90032-9

[28] Jaber, M. Y.; Neumann, W. P. (2010). Modelling worker fatigue and recovery in dual-resource constrained systems, Computers \& Industrial Engineering, Vol. 59, No. 1, 75-84, doi:10.1016/j.cie.2010.03.001

[29] Jensen, J. B. (2000). The impact of resource flexibility and staffing decisions on cellular and departmental shop performance, European Journal of Operational Research, Vol. 127, No. 2, 279-296, doi:10.1016/s0377-2217(99)00491-9

[30] Norman, B. A.; Tharmmaphornphilas, W.; Needy, K. L.; Bidanda, B.; Warner, R. C. (2002). Worker assignment in cellular manufacturing considering technical and human skills, International Journal of Production Research, Vol. 40, No. 6, 1479-1492, doi: $10.1080 / 00207540110118082$

[31] Süer, G. A.; Tummaluri, R. R. (2008). Multi-period operator assignment considering skills, learning and forgetting in labour-intensive cells, International Journal of Production Research, Vol. 46, No. 2, 469-493, doi:10.1080/00207540601138551

[32] Iida, T. (2002). A non-stationary periodic review production-inventory model with uncertain production capacity and uncertain demand, European Journal of Operational Research, Vol. 140, No. 3, 670-683, doi:10.1016/s0377-2217(01)00218-1 